\title{
Educating for the implementation of evidence-based healthcare in Brazil: the JBI methodology
}

\section{Formando para implementação de evidências em saúde no Brasil: a metodologia JBI \\ Formación para la implementación de la evidencia en salud en Brasil: la metodología del JBI}

How to cite this article:

Püschel VAA, Oliveira LB, Gomes ET, Santos KB, Carbogim FC. Educating for the implementation of evidence-based healthcare in Brazil: the JBI methodology. Rev Esc Enferm USP. 2021;55:e03718. doi: https://doi.org/10.1590/S1980-220X2020016303718

\author{
Vilanice Alves de Araújo Püschel ${ }^{1}$ \\ Larissa Bertacchini de Oliveira ${ }^{2}$ \\ Eduardo Tavares Gomes ${ }^{3}$ \\ Kelli Borges dos Santos ${ }^{4}$ \\ Fábio da Costa Carbogim 5 \\ ${ }^{1}$ Universidade de São Paulo, Escola de \\ Enfermagem, Departamento de Enfermagem \\ Médico-Cirúrgica, São Paulo, SP, Brazil. \\ Director of The Brazilian Centre of Evidence- \\ based Healthcare: A JBI Centre of Excellence \\ (JBI Brazil). Instructor of Clinical Fellowship. \\ 2 Universidade de São Paulo, Faculdade de \\ Medicina, Hospital das Clínicas, Instituto \\ do Coração, São Paulo, SP, Brazil. \\ 3 Universidade Federal de Pernambuco, \\ Departamento de Enfermagem, Hospital \\ das Clínicas, Recife, PE, Brazil. \\ ${ }^{4}$ Universidade Federal de Juiz de Fora, \\ Faculdade de Enfermagem, Departamento de \\ Enfermagem Básica, Juiz de Fora, MG, Brazil. \\ 5 Universidade Federal de Juiz de Fora, \\ Faculdade de Enfermagem, Departamento de \\ Enfermagem Aplicada, Juiz de Fora, MG, Brazil.
}

\section{ABSTRACT}

Objective: To present the JBI evidence implementation methodology and report the Brazilian experience in educating health professionals. Method: This is an experience report on professional education in the Brazilian context as per the JBI methodology. Results: In four years, 29 clinical fellows were trained in Brazil, with technical and scientific theoretical bases and tools for evidence-based practice, focusing on the transformation of the health contexts in which they are inserted. Conclusion: The JBI methodology offers systems and tools to evaluate existent practices; it also reinforces and disseminates evidence-based healthcare, potentializing the achievement of effective change in healthcare.

\section{DESCRIPTORS}

Evidence-Based Nursing; Evidence-Based Practice; Health Human Resource Training; Decision Making; Patient-Centered Care. 


\section{INTRODUCTION}

Providing care is inherent to the human condition and, in Nursing, it is a central milestone which characterizes its object of work and professional activities, related to providing integral care to individuals, families, and the collective ${ }^{(1)}$. To this end, knowledge, skills, and attitudes are required to lead to the best practices.

The best practices in nursing represent actions focused on the quality of scientific evidence, within the educational, management, clinical, and theoretical/conceptual domains ${ }^{(2)}$. This term is also used in the literature as optimal care, evidence-based directives, and clinical practice directives. It is related to concepts such as Evidence-based Practice (EBP) and quality of care, focused on the best results. The use of best practices in Nursing, based on evidence and centered on the patient, is a moral obligation of health professionals, especially nurses, to provide more than appropriate care ${ }^{(2)}$.

The term EBP, by its turn, came up in the 1970's and 1980's due to the development of the evidence-based medicine movement, when a hierarchical system with rules of evidence used to locate the best research evidence available for clinical decision-making was introduced ${ }^{(2)}$.

The EBP or Evidence Based Healthcare (EBH), which has currently been taking a prominent role in healthcare practice, derives from quality scientific evidence or even consensuses among specialists and are targeted at both care orientation and decision-making focused on the resolution of health problems ${ }^{(3-6)}$. It should be emphasized that JBI has been considering EBH to be the most appropriate term, since it implies that the best evidence available may be applied to inform policies and practices so as to improve global health ${ }^{(7-9)}$.

Thus, EBH is fundamental for improving care provision and obtaining the best results in nursing. However, clinical practice is met with gaps between produced knowledge and professional practice implementation. This is because produced knowledge is not instantaneously translated into organizational behavior and change; there are enormous gaps between recommended practice and routine care, which may lead to problems such as the exposure of health teams to unnecessary risks, low patient well-being level, and resource waste ${ }^{(7)}$.

To fulfill these gaps, some institutions, such as the Cochrane Foundation and JBI, have been developing methodologies to produce evidence synthesis ${ }^{(8-10)}$.

The JBI was founded in the 1990's by the nurse Alan Pearson and incorporated by the University of Adelaide in Australia in 2010. It is an international research and development non-profit organization which includes scientists, professionals and researchers in the health area who are committed to EBH. In October 2019, it was renamed as JBI only, ceasing to be an acronym of the name Joanna Briggs Institute. Currently, it has more than seventy Collaborating Centers in all continents (https://jbi.global/about-jbihttps:// jbi.global/about-jbi).
Brazil has a JBI Collaborating Center, which is a pioneer in Latin America, the Brazilian Center for Evidenceinformed Healthcare: JBI Center of Excellence (JBI Brazil), which disseminates the principles of EBH in Brazilian and Latin American territory, educating health professionals in the JBI methodology. In addition to educating for clinical leadership, it provides access to systems and tools to help clinicians, managers, educators, and academics/researchers to implement evidence into care practice.

The JBI Brazil, founded in 2009, is hosted in Escola de Enfermagem da Universidade de São Paulo (Universidade de São Paulo's School of Nursing - EEUSP), has a partnership with Hospital Universitário da Universidade de São Paulo (Universidade de São Paulo's University Hospital HU-USP) and maintains a covenant with JBI Australia, in University of Adelaide. It offers the courses EvidenceBased Clinical Fellowship Program - EBCFP and the Comprehensive Systematic Review Training Program, both with license, certification, and methodology of JBI.

JBI has advanced beyond its production of evidence synthesis by proposing an Evidence-based Healthcare Model ${ }^{(8)}$ and has developed a methodology for the implementation of health evidence which is currently taught in Brazil, whose results have been remarkable.

Given the inexistence of works that narrate the path of JBI in Brazil, the objective of this work is to present JBI's evidence implementation methodology and report the Brazilian experience in training health professionals for the implementation of the best evidence in health.

\section{METHOD}

\section{Design OF STUdy}

This is an experience report of JBI Brazil on the education of health professionals for the implementation of the best evidence in health.

The presuppositions of the Evidence-based Healthcare Model and the JBI Evidence Implementation Methodology $y^{(8-9)}$ are described. Characteristics of the professionals participating in the educational program for evidence implementation of JBI Brazil from 2016 to 2019 are presented.

\section{The Evidence-based HealthCare Model and the JB I EVIDENCE IMPLEMENTATION Methodology}

The JBI adopts as a theoretical framework for the construction of professional education programs the Evidencebased Healthcare Model ${ }^{(8-9)}$, represented in Figure 1.

The EBH is defined as the decision-making which considers the viability, adequacy, meaning, and effectivity of health practices, using the best evidence available, in the context in which care is provided, considering the individuality of each person and the judgment and experience of the health professional ${ }^{(8)}$. 


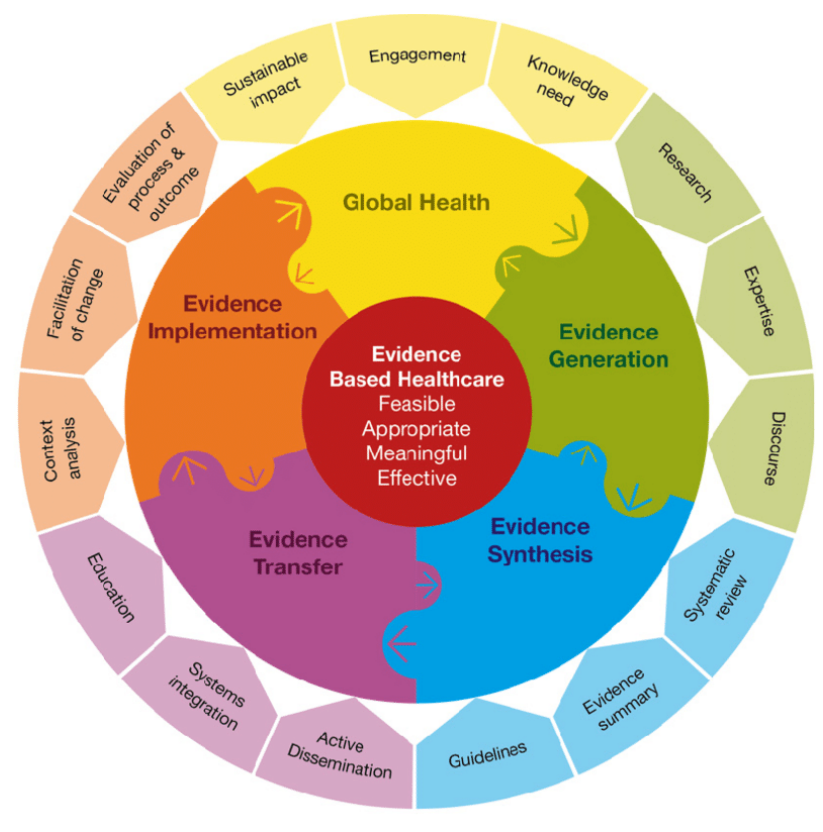

Overarching principles

Culture - Capacity - Communication - Collaboration

Figure 1 - Model of the Joanna Briggs Institute for Evidence-based Healthcare.

The pillars of EBH are: 1) generation of evidence (primary research, findings, and professional expertise); 2) evidence synthesis (systematic review, summaries of evidence and directives); 3) transference of evidence (education/formation, system integration, and active dissemination); and 4) evidence implementation (context analysis, facilitating change, and evaluation of change and results). All these components follow the steps represented by the feedback cycles ${ }^{(8)}$.

The JBI methodology for implementation of evidence consists of offering a theoretical and practical approach aimed at clinical evidence, education for clinical leadership, use of evidence, implementation of evidence in policies and practice, clinical audit and use of the tools Practical Application of Clinical Evidence System (PACES) and Getting Research into Practice (GRiP) to facilitate and guarantee registration of changes.

PACES is an online tool for data analysis and collection which enables comparing information among the baseline audits and post-audit, in one or more clinical units ${ }^{(10)}$. The clinical audit is considered a process of improvement in the quality of patient care and of the obtained results through systematic review of care, explicit criteria, and the implementation of change ${ }^{(11)}$.

The JBI model of clinical audit aims to provide more efficiency than the other EBH models, combining it to the required tools to measure the effectivity of each step ${ }^{(10)}$.

GRiP considers the barriers to change identified by the professionals in the location where the project will be implemented, the strategies used to train the health team to use evidence in practice and the process of change itself.

The use of evidence or the implementation of new knowledge encompasses three main elements: practicing change, conducting the organizational change, and evaluating the impact of the use of evidence (in the health system, in the process of care, and in the results to patient health) ${ }^{(8)}$.

Developing strategies to overcome barriers to change and the implementation of knowledge to the practice are challenges to be considered. To this end, the involved individuals need to: identify changeable and unchangeable barriers related to behavior, identify potential adopters and practice environments, and identify the barriers to be overcome $e^{(7)}$.

The course of Implementation of Evidence prepares professionals to identify and deal with the barriers that maintain the gap between the evidence of the best practices and the real practice, recognizing strategies to overcome them. In the course, strategies such as reminders, audits and feedback, educational material, opinions from leaders, didactic meetings, multifaceted interventions, as well as theoretical models that sustain educational proposals, are addressed.

These models may be helpful for the "implementer" (clinical leader) to analyze the contexts and think of measures that could be employed to subsidize an efficient implementation.

The JBI has developed, in 2013, the CLARITY model, idealized to inform the design of the project and the implementation of evidence based on the JBI's tool for audit, feedback, change, and reaudit ${ }^{(7)}$.

This model is sustained by three principles: comprehension of culture, training of individuals and organizational systems, and support infrastructure, reinforcement, and sustentation. This includes seven steps elucidated by the mnemonic CLARITY, which are: 1) Clarify the question; 2) Obtain Leadership Support; 3) Assessing existent patterns and behaviors; 4) Review the existing evidence and possible barriers; 5) Implementing the necessary changes; 6) Timed reevaluation of implemented changes and 7) Yearly review to evaluate the impact and sustainability of implemented changes ${ }^{(7)}$.

The formation for the implementation of evidence to professional clinical practice is conducted through the Evidence-Based Clinical Fellowship Program (EBCFP) or course of implementation of evidence. In 2020, the course EBCFP was renamed The JBI Evidence Implementation Training Program, maintaining the same format. The course is offered in three steps and has as objectives qualifying health professionals to implement evidence and develop knowledge and skills for managing changes and clinical leadership, according to the implementation methodology of JBI.

The first and last steps are presential, with a 35-hour workload each, and are separated by a six-month period. In the first step, the participants develop a project for the implementation of evidence; in the second step, they implement the project in a health institution, and, in the third step, they elaborate the final report and present the obtained results. Between the two presential steps, each course participant is supervised by a course facilitator (instructor) which supports and orients the project implementation. 
The theoretical approach covered in the first week of the course includes the whole framework of the course, in addition to a workshop on clinical leadership and the theoretical frameworks for the development of the evidence implementation project. Such project is conducted according to the course's participant choice of a topic of interest, made available by JBI, which contains recommendations of the best practices, based on updated evidence. Such recommendations follow criteria to be audited before and after the educational intervention with the health team.

\section{DATA COLLECTION}

The data were collected in December 2019 and refer to the courses conducted from 2016 (first enrolled class) to 2019 (last class to finish).

\section{DATA ANALYSIS AND TREATMENT}

The data were descriptively analyzed.

\section{ETHICAL ASPECTS}

Due to being an experience report, this study was not submitted to analysis by the Research Ethics Committee.

\section{RESULTS}

In Brazil, this program started in 2016, when two researchers from JBI Brazil attended, in Australia, the course Train the Trainer (TtT), by the Evidence-Based Clinical Fellowship Program (EBCFP), which enabled, for the first time, the course to be offered in Brazil and Latin America. In 2017 and 2019, TtT was offered in Brazil by JBI researchers, broadening the number of qualified instructors to eleven, all of whom were nurses.

In the four-year period, 29 clinical fellows were trained, amounting to 28 nurses and one physician, in four courses offered by JBI Brazil, since 2016. Twenty-one participants from São Paulo state (São Paulo and Sorocaba), one from Pernambuco (Recife), three from Santa Catarina (Florianópolis and Chapecó), one from Paraná (Curitiba), and three from Minas Gerais (Juiz de Fora). Chart 1 describes the work area, location, and projects implemented by course participants.

Chart 1 - Work area, location and implemented projects as per JBI methodology.

\begin{tabular}{|c|c|c|}
\hline Work area & Service of Origin & Developed implementation project \\
\hline \multirow[t]{5}{*}{$\begin{array}{l}\text { Clinical } \\
\text { nurses }\end{array}$} & $\begin{array}{l}\text { University Hospital of } \\
\text { Universidade de São } \\
\text { Paulo }\end{array}$ & $\begin{array}{l}\text { Hospitalized elderly: prevention of functional decline in the elderly in an Emergency Service of a University } \\
\text { Hospital in São Paulo } \\
\text { Breastfeeding: Signs of correct Latching and Position among Nursing Mothers in a Teaching Hospital } \\
\text { Pain evaluation during screening of adult patients in an emergency service of a university hospital in São } \\
\text { Paulo-Brazil: a project for the implementation of the best practices } \\
\text { Prevention strategies against falls in adult patients hospitalized in a university hospital in São Paulo, Brazil: a } \\
\text { project for the implementation of good practices } \\
\text { Prevention and management of primary postpartum hemorrhage among puerperal women in a university } \\
\text { hospital in São Paulo, Brazil } \\
\text { Bundle for central catheter maintenance in an adult intensive care unit of the University Hospital of } \\
\text { Universidade de São Paulo } \\
\text { Non-pharmacological interventions in the newborn in the university hospital of Universidade de São Paulo } \\
\text { Mechanical prophylaxis for the prevention of venous thromboembolism among surgical patients in a } \\
\text { university hospital } \\
\text { Care of the peripheral venous access site in patients hospitalized in a center of gynecology and obstetrics }\end{array}$ \\
\hline & $\begin{array}{l}\text { Heart Institute } \\
\text { HCFMUSP }\end{array}$ & $\begin{array}{l}\text { Management of the Peripherally Inserted Central Catheter in an Intensive Care Unit of a university hospital } \\
\text { in Brazil: a project for the implementation of good practices } \\
\text { Management of the nasogastric/nasoenteric catheter in the adult intensive care unit of a teaching hospital }\end{array}$ \\
\hline & $\begin{array}{l}\text { Municipal } \\
\text { Government of } \\
\text { Votorantim (Basic } \\
\text { Health Unit) - SP }\end{array}$ & $\begin{array}{l}\text { Self-care in adults with high blood pressure in primary healthcare: a project for the implementation of the } \\
\text { best practices }\end{array}$ \\
\hline & Sírio-Libanês Hospital & $\begin{array}{l}\text { Directive for the promotion of sleep hygiene in an intensive care unit: project for the implementation of the } \\
\text { best practices }\end{array}$ \\
\hline & $\begin{array}{l}\text { Universidade Federal } \\
\text { de Pernambuco } \\
\text { Teaching Hospital }\end{array}$ & Surgical count in abdominal and pelvic open surgery in a school hospital \\
\hline
\end{tabular}




\begin{tabular}{|c|c|c|}
\hline $\begin{array}{l}\text { Assistant } \\
\text { physician }\end{array}$ & $\begin{array}{l}\text { Dr. João Penido } \\
\text { Regional Hospital - } \\
\text { Juiz de Fora }\end{array}$ & Insertion of central venous catheter in adult patients: a project for the implementation of the best practices \\
\hline \multirow{7}{*}{ Professors } & $\begin{array}{l}\text { University of São } \\
\text { Paulo's School of } \\
\text { Nursing - São Paulo }\end{array}$ & $\begin{array}{l}\text { Intrapartum care in a public teaching hospital: a project for the implementation of the best practices } \\
\text { Tracking, assessment, and management of delirium in ICU } \\
\text { Planning discharge for nasoenteral feeding in patients with cancer in a teaching hospital in Brazil }\end{array}$ \\
\hline & $\begin{array}{l}\text { School of Arts, } \\
\text { Sciences, and } \\
\text { Humanities }\end{array}$ & $\begin{array}{l}\text { Perineal repair in intrapartum care in a public hospital in a municipality in São Paulo: a project for the } \\
\text { implementation of the best practices }\end{array}$ \\
\hline & $\begin{array}{l}\text { Senac University } \\
\text { Center - SP }\end{array}$ & Nursing clinical supervision among nurses of medical clinics in two hospitals in São Paulo \\
\hline & $\begin{array}{l}\text { Universidade do } \\
\text { Estado de Santa } \\
\text { Catarina }\end{array}$ & $\begin{array}{l}\text { Hand hygiene among nursing professionals in an emergency service } \\
\text { Assessment of the surgical checklist in a surgical center of a regional hospital in Western Santa Catarina }\end{array}$ \\
\hline & $\begin{array}{l}\text { Universidade Federal } \\
\text { do Paraná }\end{array}$ & Totally implanted catheter management in a pediatric unit \\
\hline & $\begin{array}{l}\text { Universidade Federal } \\
\text { de Santa Catarina }\end{array}$ & $\begin{array}{l}\text { Transition of care of elderly people hospitalized in a surgical clinic of a São Paulo university hospital to the } \\
\text { domicile: a project for the implementation of the best practices }\end{array}$ \\
\hline & $\begin{array}{l}\text { Universidade Federal } \\
\text { de Juiz de Fora } \\
\text { (Universidade Federal } \\
\text { de Juiz de Fora } \\
\text { University Hospital) } \\
\end{array}$ & Chemotherapy - Nursing registers in the Bone Marrow Transplantation Unit of a university hospital \\
\hline $\begin{array}{l}\text { PhD } \\
\text { student }\end{array}$ & $\begin{array}{l}\text { School of Nursing of } \\
\text { USP (Dante Pazzanese } \\
\text { Cardiology Institute) }\end{array}$ & Transitional care from hospital to domicile among people with cardiac insufficiency: \\
\hline $\begin{array}{l}\text { Masters' } \\
\text { candidate } \\
\text { and } \\
\text { assistant } \\
\text { nurse }\end{array}$ & $\begin{array}{l}\text { Nursing Faculty of } \\
\text { Universidade Federal } \\
\text { de Juiz de Fora } \\
\text { (Kidney Diseases } \\
\text { Treatment Center of } \\
\text { Juiz de Fora) }\end{array}$ & Kidney transplant - Interventions to improve medication adherence of post-transplantation adult patients \\
\hline $\begin{array}{l}\text { Nurse } \\
\text { Consultant }\end{array}$ & $\begin{array}{l}\text { Health auditor and } \\
\text { consultant }\end{array}$ & $\begin{array}{l}\text { Application of a structured communication tool in the multidisciplinary visit in the adult ICU of a private } \\
\text { hospital in a municipality in São Caetano do Sul }\end{array}$ \\
\hline
\end{tabular}

Out of 28 nurses, 15 provided care, ten were involved in teaching, one was a Nursing consultant, one was a $\mathrm{PhD}$ student, and another was a Master's student, in EEUSP and UFJF (Universidade Federal de Juiz de Fora), respectively.

The physician is a thoracic surgeon and works at a hospital in the municipality of Juiz de Fora, in Minas Gerais state. In addition to the 29 clinical fellows, other five nurses - one of them from Uruguay - were unable to conclude the course due to personal problems or a delay in the Ethics Committee and should finish it in the next offering.

Following the JBI methodology, each course participant elaborated, implemented, and assessed the obtained results with the implementation of a project in one of the themes for which JBI has synthesized the best practices. In this process, the course participant chose one from almost five hundred topics previously synthesized by JBI on the best practices based on scientific evidence (the topics are available in: https://wiki. joannabriggs.org/display/PT). Also, the participant constituted a nuclear team in the Unit where the project was implemented; performed the baseline audit to understand to what extent the professionals were in accordance with the best practices criteria; formed the team and, after a timespan defined in the project, performed the follow-up audit.
In the second presential meeting, they inserted the results of the baseline and follow-up audits into the PACES tool, elaborated the final report for the implemented projects and publicly presented the results obtained for the community of the School of Nursing of USP and for nurses of HU-USP. From the third offering onwards, the results were presented in the National Meeting for Evidence Implementation in Health Institutions (Encontro Nacional de Implementação de Evidências em Instituiçôes de Saúde - ENIES), which had its second edition in 2019, with 167 participants.

Considering the developed projects, interest was noted for clinical approaches in patient care, prevention of aggravation, promotion of well-being, device management, patient safety, planning of discharge and care in the transition from hospital to domicile, clinical Nursing supervision, non-pharmacological interventions, health education, tracking, assessment, and management of health problems, treatment adherence, structured communication, and self-care of chronic disease in different clinical contexts, both in specialized and primary health care (Chart 1$)$.

The participants have reported a high level of satisfaction with the course for evidence implementation due to learning a methodology which has indeed been transforming the health contexts in which they are inserted. 


\section{DISCUSSION}

Approaching the precepts of $\mathrm{EBH}$ has provided evidence regarding the gaps between necessary and discovered knowledge, published science and clinical application, and clinical practice and necessary changes in the policies and practices of health services. Integrating the translational gaps and the precepts of EBH seems to be what better expresses the complexity of the translation of knowledge into action ${ }^{(12)}$.

The results of the projects of best practices implemented in the health services have been showing a high percentage of conformity of the criteria after the follow-up audition, many of which achieve the totality of conformity compatible with the best evidence. These favorable results may be seen in some publications of the alumni ${ }^{(13-17)}$.

The implementation of evidence has been achieving the status of a new area of knowledge by relating robust scientific bases for improving the care practice and increasing its impact on public health ${ }^{(18)}$.

However, establishing the efficacy of a scientific innovation does not guarantee its broad and deliberate use in daily clinical practice. This process may take from 17 to 20 years to be implemented in clinical practice and less than $50 \%$ of the clinical innovations make it into general use ${ }^{(18)}$. Considering the practice changes which occurred from the implementation of the projects, the JBI methodology contributes to reduce this time and the gap between the produced evidence and its use in care practice. As a challenge, it is necessary to watch for the sustainability of the implemented changes.

The science of implementation is emphasized to present characteristics and approaches which parallel the rigor of clinical research. Moreover, it broadens its scope by including plans of actions which consider the optimization of elements which facilitate change, as well as the identification of barriers to be faced aiming at the improvement of care results, reduction of costs, and increase in satisfaction of the involved parts (professionals, patients, managers, and others) ${ }^{(18-19)}$.

Some factors may be considered influential in the process of implementing nursing evidences, including: organizational culture and environment, nursing leadership, hospital size, staff support, organizational innovation, capacity for response by the administration, access to resources, offer of education, access to research results, availability of knowledge and skills within organizations, integration of recommendations within organizational structures and processes, interorganizational collaboration, financial resources, workload, resistance to change, and time ${ }^{(20)}$.

In this perspective, the JBI model is used as a tool to contribute to boost $\mathrm{EBH}$ by approaching and considering such factors in the formation of the professional and in the development of projects for the implementation of Health evidence $^{(12)}$. Over 600 clinical fellows have been trained in more than 30 countries and, although the authors conclude that there are few publications on the implementation of Health evidence, the methodology has been employed as an organizational tool in Health services and in $\mathrm{JBI}^{(8-10)}$.

In this sense, JBI Brazil is a pioneer and forefront of the EBP movement in Latin America by offering courses for the implementation of evidence in the JBI methodology. The course is an innovation for the health professionals and has in nursing the protagonist of this movement.

Such aspect has been giving enormous visibility to Nursing and starts to get attention from other areas within health. The efforts are thus salutary since they enable the development of strategies which orient the actions of health professionals, making them capable of approaching scientific discoveries to clinical practice ${ }^{(19)}$.

\section{CONCLUSION}

Reflecting on good nursing practices enables rethinking care and its dimensions as a central role in nursing actions which should be supported by scientific evidence, aligning professional experience and preferences of the care subjects in the context where this care is provided.

The evidence-based healthcare model of JBI offers systems and tools to assess existent practices, reinforcing and disseminating the implementation of the best practices in Nursing and health, reaching effective results for the necessary changes in healthcare. This is the experience that JBI Brazil has been living by training nurses for effectively implementing the best evidence in the contexts where they are inserted.

This is believed to be in its beginning, with much to advance, given the large Brazilian territory and the potentials for advances in Latin America. However, clinical fellows are clinical leaders inserted in health services which have implemented projects and seen the excellent results, in addition to having been contemplated with important awards and recognition. Also, many course participants are professors who are mobilized by the potentiality of this methodology and have been teaching evidence-based healthcare to a new generation of nurses. We are on our way...

\section{RESUMO}

Objetivo: Apresentar a metodologia de implementação de evidências do JBI e relatar a experiência brasileira na formação de profissionais de saúde. Método: Trata-se de relato de experiência sobre a formação profissional no contexto brasileiro segundo a metodologia JBI. Resultados: Em quatro anos, foram formados 29 clinical fellows no Brasil, com bases teóricas e ferramentas técnico-científicas da prática baseada em evidências, focando a transformação das realidades de saúde em que se inserem. Conclusão: A metodologia do JBI oferece sistemas e ferramentas que avaliam as práticas existentes, além de reforçar e disseminar o cuidado em saúde baseado em evidências, possibilitando o alcance de mudanças efetivas no cuidado em saúde. 
DESCRITORES

Enfermagem Baseada em Evidências; Prática Clínica Baseada em Evidências; Capacitação de Recursos Humanos em Saúde; Tomada de Decisões; Assistência Centrada no Paciente.

\section{RESUMEN}

Objetivo: Presentar la metodología para la implementación de la evidencia del JBI y reportar la experiencia brasileña en la formación de los profesionales de la salud. Método: Este es un informe de experiencia sobre la formación profesional en el contexto brasileño según la metodología del JBI. Resultados: En cuatro años, 29 clinical fellows fueron formados en Brasil con fundamentos teóricos y herramientas técnico-científicas de la práctica basada en la evidencia, con enfoque en la transformación de los contextos de salud en los que están insertos. Conclusión: La metodología del JBI ofrece sistemas y herramientas para evaluar las prácticas existentes, además de fortalecer y difundir la atención sanitaria basada en la evidencia, permitiendo lograr cambios efectivos en la atención sanitaria.

\section{DESCRIPTORES}

Enfermería Basada en la Evidencia; Práctica Clínica Basada en la Evidencia; Capacitación de Recursos Humanos en Salud; Toma de Decisiones; Atención Dirigida al Paciente.

\section{REFERENCES}

1. Bertoncini JH, Pires DEP, Ramos FRS. Dimensões do trabalho da enfermagem em múltiplos cenários institucionais. Tempus Actas Saúde Coletiva. 2011;5(1):123-33. http://doi.org/10.18569/tempus.v5il.922

2. Nelson AM. Best practice in nursing: a concept analysis. Int J Nurs Stud. 2014;51(11):1507-16. https://doi.org/10.1016/j.ijnurstu.2014.05.003

3. Kim JS, Gu MO, Chang H. Effects of an evidence-based practice education program using multifaceted interventions: a quasi-experimental study with undergraduate nursing students. BMC Med Educ. 2019;19(1):71. doi: 10.1186/s12909-019-1501-6

4. Oh EG, Yang YL. Evidence-based nursing education for undergraduate students: a preliminary experimental study. Nurse Educ Pract. 2019;38:45-51. doi: 10.1016/j.nepr.2019.05.010

5. Hung H-Y, Huang Y-F, Tsai J-J, Chang Y-J. Current state of evidence-based practice education for undergraduate nursing students in Taiwan: a questionnaire study. Nurse Educ Today. 2015;35(12):1262-7. doi: 10.1016/j.nedt.2015.05.001

6. Horntvedt M-ET, Nordsteien A, Fermann T, Severinsson E. Strategies for teaching evidence-based practice in nursing education: a thematic literature review. BMC Med Educ. 2018;18(1):172. doi: 10.1186/s12909-018-1278-z

7. Grimshaw JM, Eccles MP, Lavis JN, Hill SJ, Squires JE. Knowledge translation of research findings. Implement Sci. 2012;7:50. doi: 10.1186/1748-5908-7-50

8. Jordan Z, Lockwood C, Munn Z, Aromataris E. The updated Joanna Briggs Institute model for evidence-based healthcare. Int J Evid Based Healthc. 2019;17(1):58-71. doi: 10.1097/XEB.0000000000000155

9. Püschel VAA, Lockwood C. Translating knowledge: Joanna Briggs Institute's expertise [editorial]. Rev Esc Enferm USP. 2018;52:e03344 doi: http://dx.doi.org/10.1590/S1980-220X2018ed0103344

10. Jordan Z, Lockwood C, Munn Z, Aromataris E. Redeveloping the JBI Model of Evidence Based Healthcare. Int J Evid Based Healthc. 2018;16(4):227-41. doi:10.1097/XEB.0000000000000139

11. National Institute for Clinical Excellence. Principles for best practice in clinical audit [Internet]. Abingdon: Radcliffe Medical Press; 2002 [cited 2020 Aug 18]. Available from: https://www.nice.org.uk/media/default/About/what-we-do/Into-practice/principles-for-best-practicein-clinical-audit.pdf

12. Pearson A. Balancing the evidence: incorporating the synthesis of qualitative data into systematic reviews. JBI Rep. 2004;2:45-64. doi: https://doi.org/10.1111/j.1479-6988.2004.00008.x

13. Sichieri K, Lida LIS, Menezes IRSC, Garcia PC, Santos TR, Peres E, et al. Central line bundle maintenance among adults in a university hospital intensive care unit in São Paulo, Brazil: a best practice implementation project. JBI Database System Rev Implement Rep. 2018;16(6):1454-73. doi: 10.11124/JBISRIR-2017-003561

14. Poveda VB, Silva AM, Toyama AC, Silva JA, Shimoda GT, Püschel VAA. Nasoenteric feeding discharge planning for cancer patients in a Brazilian teaching hospital: a best practice implementation project. JBI Database System Rev Implement Rep. 2018;16(5):1269-81. doi: 10.11124 /JBISRIR-2017-003506

15. Ogawa L, Shimoda GT, Wei CY, Püschel VAA. Prevention and management of primary postpartum hemorrhage among puerperae in a teaching hospital in São Paulo, Brazil: a best practice implementation project. JBI Database System Rev Implement Rep. 2019;17(3):41428. doi: 10.11124/JBISRIR-2017-003830

16. Oliveira LB, Fava YR, Rodrigues ARB, Franulovic AC, Ferreira NT, Püschel VAA. Management of peripherally inserted central catheter use in an intensive care unit of a teaching hospital in Brazil. JBI Database System Rev Implement Rep. 2018;16(9):1874-86. doi: 10.11124/ JBISRIR-2017-003577

17. Santos KB, Campos CS, São José Perrone ACA, Araújo CMVS, Coelho DP, Hallack-Neto AE, Lockwood C, Püschel VAA. Nursing documentation for chemotherapy in a university hospital's bone marrow transplant unit: a best practice implementation project. Int J Evid Based Healthc. 2020;18(1):75-85. doi: 10.1097/XEB.0000000000000216

18. Bauer MS, Kirchner J. Implementation science: What is it and why should I care? Psychiatry Res. 2020;283:112376. doi: https://doi. org/10.1016/ j.psychres.2019.04.025

19. Püschel VAA. ¿Como formar o enfermeiro para a prática baseada em evidências? Rev Iberoam Educ Invest Enferm [Internet]. 2018 [citado 2020 Aug 18];8(3):4-6. Disponible en: https://www.enfermeria21.com/revistas/aladefe/articulo/281/como-formar-o-enfermeiro-para-apratica-baseada-em-evidencias/ 
20. van Achterberg T, Schoonhoven L, Grol R. Nursing Implementation science: how evidence-based nursing requires evidence-based implementation. J Nurs Scholars. 2008;40(4):302-10. doi: 10.1111/j.1547-5069.2008.00243.x

Financial support:

Universidade Federal de Juiz de Fora.

Acknowledgements:

To JBI Brazil and the peers who teach the course Evidence-Based Clinical Fellowship Program (EBCFP).

\section{ERRATUM}

On page 1, affiliation 1:

Where was written:

${ }^{1}$ Universidade de São Paulo, Escola de Enfermagem, Departamento de Enfermagem Médico-Cirúrgica, São Paulo, SP, Brazil.

Now read:

${ }^{1}$ Universidade de São Paulo, Escola de Enfermagem, Departamento de Enfermagem Médico-Cirúrgica, São Paulo, SP, Brazil. Director of The Brazilian Centre of Evidence-based Healthcare: A JBI Centre of Excellence (JBI Brazil). Instructor of Clinical Fellowship. 